\title{
Gene flow in the Daphnia longispina hybrid complex (Crustacea, Cladocera) inhabiting large lakes
}

\author{
SABINE GIEßLER* \\ Zoologisches Institut der Universität München, Kar/straße 25, D-80333 Munich, Germany
}

\begin{abstract}
The significance of short-term exchange between populations relative to long-term local selection was evaluated in the Daphnia longispina hybrid complex. In a hierarchical analysis, the genetic structure of $D$. cucullata, $D$. hyalina and their interspecific hybrid $c \times h$ was studied by allozyme electrophoresis. Two data sets based on the variation at three and nine loci revealed high genetic variation in all populations. Significant genetic differentiation, $F_{\mathrm{ST}}$, was found between lakes that are less than $14 \mathrm{~km}$ apart. $F_{\mathrm{ST}}$ between subpopulations was around 0.2 for $D$. hyalina and $D$. cucullata averaged over three and nine loci. Selection on hybrid genomes may explain why, in $c \times h$ hybrids, only 10 per cent of the total genetic variation found was attributable to differences between populations. $F_{\mathrm{ST}}$ and genetic distances, $D_{\text {nei }}$, were compared between pairs of populations from different hierarchical levels. In both data sets, differences were highest between species. Between parent species and hybrids, they were intermediate, and they were lowest within species. A regression of $\log \mathrm{Nm}$ against log distance was used to test for isolation by distance. Mantel tests showed a highly significant decrease in $\mathrm{Nm}$ with distance for populations of $D$. hyalina in both data sets. A negative trend was also found for populations of $D$. cucullata and $c \times h$. Thus, in contrast to littoral cladoceran species, the pattern of geographical variation between populations of pelagic species seems to be more strongly influenced by gene flow.
\end{abstract}

Keywords: Daphnia, F-statistics, gene flow, hybridization, isozymes, species complex.

\section{Introduction}

Gene flow between populations is an important factor influencing the degree of genetic variation within and between populations (Slatkin, 1987). The genetic exchange between populations depends on both the dispersal ability of the organism and the probability of migrants successfully mating with residents. For freshwater zooplankton, such as cladocerans (Crustacea) and rotifers, the overall population structure is strongly influenced by the island-like distribution of lakes and ponds. Within lake districts, migration between subpopulations is facilitated by temporal flooding and by interconnecting rivers. Gene flow between lake systems is severely limited by the occurrence of suitable 'vectors', such as wind or water fowl, and usually restricted to dry-resistant stages. Therefore, populations of zooplankton species can be regarded as building a network of

*E-mail: sabine.giessler@zoologie.biologie.uni-muenchen.d400.de exchange between neighbouring populations, with some long-distance dispersal superimposed. The degree of exchange and the intensity of local selection will determine whether isolation by distance becomes apparent in genetic analysis.

The genetic population structure of the cladoceran genus Daphnia is strongly influenced by the type of breeding system. Much is known about pond and littoral species, in which the main reproduction mode is cyclic parthenogenesis: bisexual reproduction (production of resting eggs, which are encapsulated in a dry-resistant 'ephippium') alternating with apomictic (clonal) parthenogenetic phases. After bisexual reproduction, high clonal diversity and agreement with Hardy-Weinberg $(\mathrm{H}-\mathrm{W})$ expectations have been found. On the other hand, low clonal diversity and strong deviation from $\mathrm{H}-\mathrm{W}$ have been described for populations of permanent ponds with a low degree of bisexual reproduction (Hebert, 1987). In pelagic species from permanent lakes, the genetic population structure is different 
from that found in permanent ponds. Here also, parthenogenetic reproduction is continuous, and only occasionally is bisexual reproduction by a small fraction of the population superimposed (Jacobs, 1990). However, population size is usually large and clonal diversity was found to be generally high and independent of the extent of bisexual reproduction (Mort \& Wolf, 1986). Deviations from H-W expectations appear to be highly variable, which might be partly the result of taxonomic confusion. Molecular methods revealed interspecific hybridization and improved taxonomic identification (Hebert, 1985; Wolf \& Mort, 1986; Hebert et al., 1989; Taylor \& Hebert, 1993; Gießler, 1997). F F-hybrids may become extremely abundant and sometimes outcompete one or both parental species (Taylor \& Hebert, 1992). Within lakes, gene flow between species seems to be generally restricted, but high degrees of introgression have also been reported (Mort \& Wolf, 1986; Hebert et al., 1989; Schwenk, 1993; Taylor \& Hebert, 1993; Spaak, 1996). Thus, in hybrid complexes, two processes must be separated in the analysis of gene flow: (i) gene flow between parental species through hybridization within lakes; and (ii) the within-species exchange of individuals between lakes.

In Europe, most pelagic species belong to the Daphnia longispina complex. The most frequent species are $D$. cucullata, $D$. galeata, $D$. hyalina and $D$. longispina. In prealpine lakes, populations of these species originated with postglacial recolonization about 8000 years ago. It is to be expected that the time of divergence and population size will co-determine the genetic differentiation of subpopulations. The likelihood of observing isolation by distance will depend on both the correlation between dispersal rate and geographical distance and the extent of local selection on colonizers. If selection is high, a relationship between gene flow and geographical distance will only be observed in cases of high exchange. If selection is low, say the ecology of the habitats is very similar, even rare colonizers have the chance to establish themselves in local populations favoured by parthenogenetic reproduction. The significance of exchange to lakespecific selection may differ between large-lake Daphnia and littoral Daphnia.

Few studies have addressed the analysis of gene flow in large-lake Daphnia (Mort \& Wolf, 1986; Jacobs, 1990) and the inconsistent results reported might partly result from insufficient taxonomic resolution within hybrid complexes. Nothing is known about the significance of recurrent local hybridization relative to the limited dispersal of hybrids between lakes. In this study, gene flow between pelagic populations of two species of the $D$. longispina complex, D. hyalina and $D$. cucullata, and their hybrids, $c \times h$, will be analysed. The following questions are addressed:

1 What is the genetic population structure of species and hybrids?

2 Is the genetic similarity between populations random in space?

3 How much gene flow is there between populations?

The measurement of the genetic structure of populations is based on allozyme data. Rates of gene flow between populations of the same taxon from different lakes and between taxa within the same lake are estimated on the basis of the distribution of alleles, genotypes and $F_{\mathrm{ST}}$ values. I expect that the spatial genetic structure will reflect the relative forces of long-term local selection and short-term exchange.

\section{Materials and methods}

\section{Species and sampling}

The samples of $D$. hyalina, D. cucullata and their hybrids (D. cucullata $\times D$. hyalina: $c \times h)$ analysed in this report were collected within the frame of a broader project on microevolution in the $D$. longispina complex. A hierarchical sampling design was used to analyse the spatial subdivision of natural populations. The animals originated from the populations of nine prealpine lakes in southern Germany near the Chiemsee (district I with six lakes and district II with three lakes), and from one lake in north-west Germany $500 \mathrm{~km}$ away, the Meerfelder Maar (district III). Districts I and II are neighbouring, but independent of each other (Fig. 1). Some of the lakes were temporarily connected by streams (four in district I and two in district II). Short-term connected lakes, as well as long-term isolated lakes, were sampled to cover a broad range of exchange between populations. The maximum geographical distance was between the Obinger See and Langbürgner See $(13.3 \mathrm{~km})$, and the smallest was between the Mittersee and the Jägersee $(200 \mathrm{~m})$. Most of the lakes are eutrophic; only the Brunnsee and the Langbürgner See may be classified as mesotrophic. Some of the lakes were dystrophic brownish moor lakes (Griessee and Pelhamer See). Lake areas ranged from 10 to 90 ha, maximum depths from 12 to $37 \mathrm{~m}$, and lake volumes from $0.04 \times 10^{6}-15 \times 10^{6} \mathrm{~m}^{3} \quad$ (Siebeck, 1991; Müller, 1993). Zooplankton samples were taken in multiple 
vertical hauls from the bottom of the lake to the top using a plankton net (mesh size $250 \mu \mathrm{m}, 45 \mathrm{~cm}$ diameter), and transported alive to the laboratory. Within the first few hours, the daphnids were picked out and subjected to morphological identification (Gießler, 1987, 1997) using a microscope. Random subsamples of females from the required taxa were subsequently frozen in liquid nitrogen. Daphnia hyalina was collected most extensively. In May 1985, populations were sampled simultaneously in five lakes: Brunnsee (two sites), Hartsee (two sites), Klostersee, Langenbürgner See (two sites) and Pelhamer See (Fig. 1 and Table 1). Between July 1983 and July 1985, samples were taken at varying intervals in eight lakes (in addition to the five lakes above, in the Mittersee, Jägersee and Obinger See; Fig. 1). Daphnia cucullata and $c \times h$ hybrids were collected only once, in June $1985 ; D$. cucullata in five lakes, hybrids in four lakes (Table 1). Small

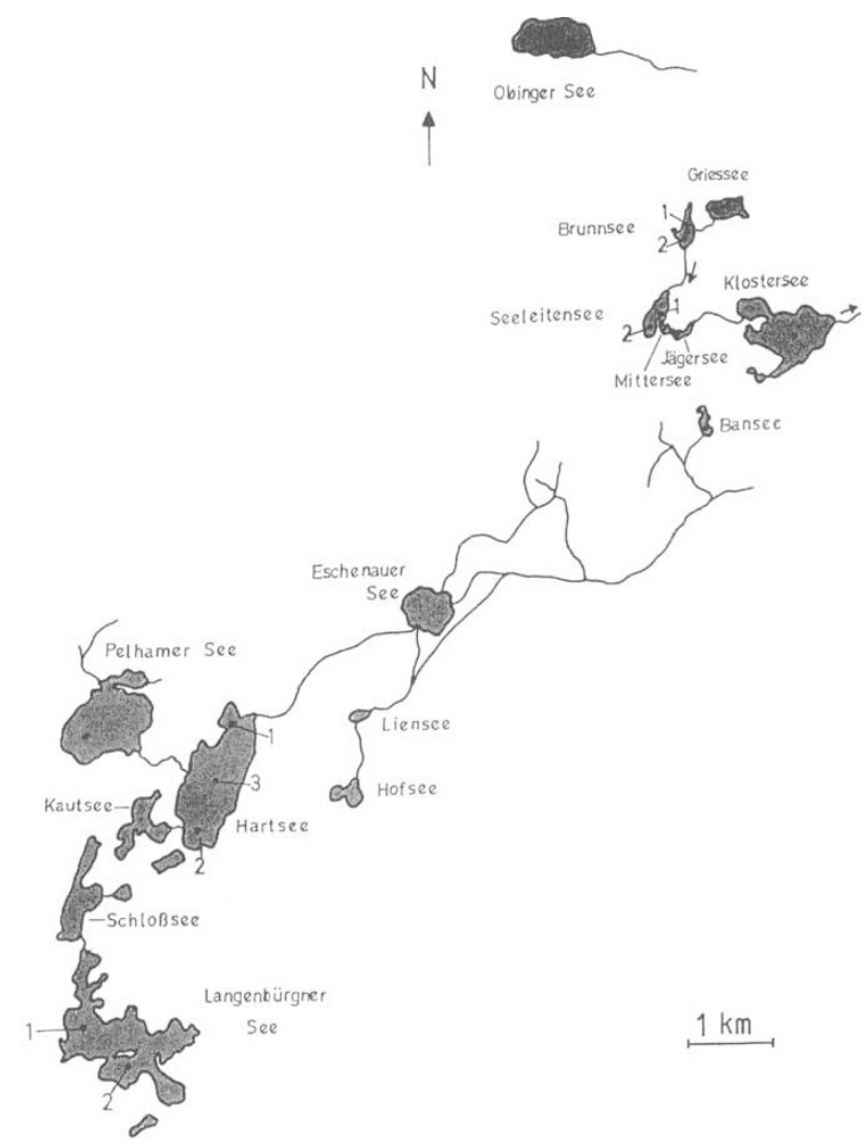

Fig. 1 Sampling sites and origin of animals of the Daphnia longispina complex studied. Lake district I: Brunnsee, Griessee, Jägersee, Klostersee, Mittersee, Obinger See and Seeleitensee. Lake district II: Hartsee, Langenbürgner See and Pelhamer See. (•) Sampling sites. Only two sites in Hartsee $(1,2)$ were used in the present study. population sizes in some of the lakes allowed the analysis of only a few individuals. To gain a broader perspective on the spatial scale of the population structure, the results were compared with those from a different study. Between 1985 and 1987, 122 clones were established in the laboratory, 49 clones from six populations of $D$. hyalina, 21 clones from four populations of $D$. cucullata and 52 clones from four populations of $c \times h$ hybrids. The animals came from seven lakes: six lakes from the lake districts I and II, and one from district III (Table 2).

\section{Electrophoresis}

The animals collected in the field were analysed at three polymorphic loci by starch-gel electrophoresis (methods in Wolf, 1982) coding for glucose-6-phosphate isomerase (EC 5.3.1.9; GPI), glutamate-oxalacetate transaminase (EC 2.6.1.1; GOT) and phosphoglucomutase (EC 5.4.2.2; PGM). The laboratory clones were analysed at nine loci by cellulose acetate electrophoresis (Hebert \& Beaton, 1989). Several individuals were pooled for each test. In addition to Gpi, Got and Pgm, the following loci were tested, coding for aldehyde oxidase (EC 1.2.3.1; AO), malate dehydrogenase (EC 1.1.1.37; $\mathrm{MDH}$ ), mannose-6-phosphate isomerase (EC 5.3.1.8; MPI), three peptidases [EC 3.4.11/13: PEP1 (substrate L-leucyl-L-alanine); PEP2.1 (substrate L-leucyl-glycylglycine); PEP3 (substrate L-valyl-L-leucine)]. Allozymes were designated numerically according to their electrophoretic mobility relative to reference marker animals from laboratory clones.

\section{Data analysis}

Deviation from Hardy-Weinberg proportions were calculated using Weir \& Cockerham's (1984) estimate of $F_{1 \mathrm{IS}}$, and the Markov chain method was used to estimate the exact $P$-value (Guo \& Thompson, 1992) using the GENEPOP program (Raymond \& Rousset, 1995). Allele frequency divergence between populations was quantified by calculating $F_{\text {ST }}$ per pair of samples according to Wright's $F$-statistic, using the algorithm described by Weir \& Cockerham (1984). The variance of $F_{\mathrm{ST}}$ was estimated with the jackknife procedure and corrected for small samples using the FSTAT program (Goudet, 1995). Tests for significance of $F_{\mathrm{ST}}$ were carried out for each locus individually, and over all loci using permutations. Rejection levels were adjusted using Bonferroni procedures. Genetic distance, $D_{\text {nei }}$ (Nei, 1972), between populations was calculated conventionally to allow comparisons with values from other studies. 


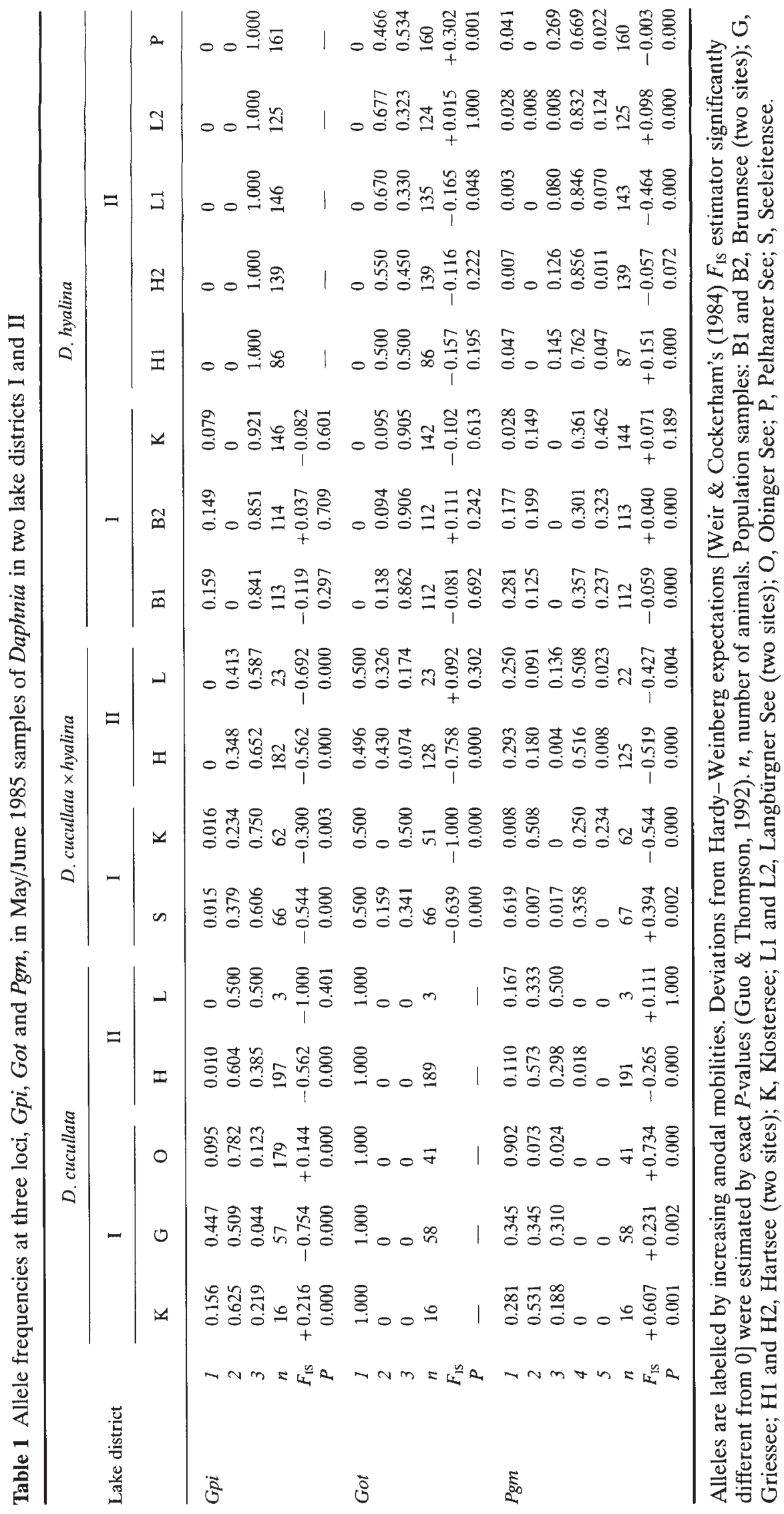

() The Genetical Society of Great Britain, Heredity, 79, 231-241. 
Table 2 Allele frequencies within populations of the Daphnia cucullata-hyalina complex sampled between 1985 and 1987

\begin{tabular}{|c|c|c|c|c|c|c|c|c|c|c|c|c|c|c|c|}
\hline \multirow{3}{*}{ Lake district } & & \multicolumn{4}{|c|}{ cuc } & \multicolumn{4}{|c|}{$c \times h$} & \multicolumn{6}{|c|}{ hya } \\
\hline & & \multicolumn{2}{|c|}{ I } & \multicolumn{2}{|c|}{ II } & \multirow{2}{*}{$\frac{\mathrm{I}}{\mathrm{K}}$} & \multicolumn{2}{|c|}{ II } & \multirow{2}{*}{$\frac{\text { III }}{M}$} & \multicolumn{3}{|c|}{ I } & \multicolumn{3}{|c|}{ II } \\
\hline & & $\mathrm{O}$ & $\mathrm{K}$ & $\mathrm{H}$ & L & & $\mathrm{H}$ & L & & B & $\mathrm{O}$ & $\mathrm{K}$ & $\mathrm{H}$ & $\mathrm{L}$ & $\mathrm{P}$ \\
\hline$A o$ & $\begin{array}{l}1 \\
2 \\
3 \\
n\end{array}$ & $\begin{array}{l}0 \\
0 \\
1.00 \\
1\end{array}$ & $\begin{array}{l}0 \\
0 \\
1.00 \\
15\end{array}$ & $\begin{array}{l}0 \\
0 \\
1.00 \\
1\end{array}$ & $\begin{array}{l}0 \\
0 \\
1.00 \\
3\end{array}$ & $\begin{array}{l}0 \\
0.33 \\
0.67 \\
3\end{array}$ & $\begin{array}{l}0 \\
0.50 \\
0.50 \\
34\end{array}$ & $\begin{array}{l}0 \\
0.50 \\
0.50 \\
6\end{array}$ & $\begin{array}{l}0 \\
0.50 \\
0.50 \\
8\end{array}$ & $\begin{array}{l}0 \\
1.00 \\
0 \\
4\end{array}$ & $\begin{array}{l}0 \\
1.00 \\
0 \\
1\end{array}$ & $\begin{array}{l}0.37 \\
0.63 \\
0 \\
15\end{array}$ & $\begin{array}{l}0 \\
0.98 \\
0.02 \\
29\end{array}$ & $\begin{array}{l}0 \\
1.00 \\
0 \\
2\end{array}$ & $\begin{array}{l}0 \\
1.00 \\
0 \\
8\end{array}$ \\
\hline Got & $\begin{array}{l}1 \\
2 \\
3 \\
n\end{array}$ & $\begin{array}{l}1.00 \\
0 \\
0 \\
1\end{array}$ & $\begin{array}{l}1.00 \\
0 \\
0 \\
16\end{array}$ & $\begin{array}{l}1.00 \\
0 \\
0 \\
1\end{array}$ & $\begin{array}{l}1.00 \\
0 \\
0 \\
3\end{array}$ & $\begin{array}{l}0.50 \\
0 \\
0.50 \\
3\end{array}$ & $\begin{array}{c}0.50 \\
0.28 \\
0.22 \\
34\end{array}$ & $\begin{array}{c}0.50 \\
0.25 \\
0.25 \\
6\end{array}$ & $\begin{array}{l}0.50 \\
0.50 \\
0 \\
8\end{array}$ & $\begin{array}{l}0 \\
0 \\
1.00 \\
4\end{array}$ & $\begin{array}{l}0 \\
0.50 \\
0.50 \\
1\end{array}$ & $\begin{array}{l}0 \\
0.20 \\
0.80 \\
15\end{array}$ & $\begin{array}{l}0 \\
0.57 \\
0.43 \\
29\end{array}$ & $\begin{array}{l}0 \\
1.00 \\
0 \\
2\end{array}$ & $\begin{array}{l}0 \\
0.50 \\
0.50 \\
8\end{array}$ \\
\hline$G p i$ & $\begin{array}{l}1 \\
2 \\
3 \\
n\end{array}$ & $\begin{array}{l}0 \\
1.00 \\
0 \\
1\end{array}$ & $\begin{array}{l}0.07 \\
0.93 \\
0 \\
14\end{array}$ & $\begin{array}{l}0 \\
0.50 \\
0.50 \\
1\end{array}$ & $\begin{array}{l}0 \\
0.50 \\
0.50 \\
3\end{array}$ & $\begin{array}{l}0 \\
0.33 \\
0.67 \\
3\end{array}$ & $\begin{array}{l}0 \\
0.41 \\
0.59 \\
34\end{array}$ & $\begin{array}{l}0 \\
0.17 \\
0.83 \\
6\end{array}$ & $\begin{array}{l}0.13 \\
0 \\
0.88 \\
8\end{array}$ & $\begin{array}{l}0.13 \\
0 \\
0.88 \\
\quad 4\end{array}$ & $\begin{array}{l}0 \\
0 \\
1.00 \\
1\end{array}$ & $\begin{array}{l}0 \\
0 \\
1.00 \\
15\end{array}$ & $\begin{array}{l}0 \\
0 \\
1.00 \\
29\end{array}$ & $\begin{array}{l}0 \\
0 \\
1.00 \\
2\end{array}$ & $\begin{array}{l}0 \\
0 \\
1.00 \\
8\end{array}$ \\
\hline$M d h$ & $\begin{array}{l}1 \\
2 \\
3 \\
n\end{array}$ & $\begin{array}{l}0 \\
1.00 \\
0 \\
2\end{array}$ & $\begin{array}{l}0 \\
1.00 \\
0 \\
16\end{array}$ & $\begin{array}{l}0 \\
1.00 \\
0 \\
1\end{array}$ & $\begin{array}{l}0.17 \\
0.83 \\
0 \\
3\end{array}$ & $\begin{array}{l}0 \\
1.00 \\
0 \\
3\end{array}$ & $\begin{array}{l}0.37 \\
0.63 \\
0 \\
34\end{array}$ & $\begin{array}{l}0.33 \\
0.67 \\
0 \\
6\end{array}$ & $\begin{array}{c}0.13 \\
0.81 \\
0.06 \\
8\end{array}$ & $\begin{array}{l}0 \\
0.75 \\
0.25 \\
4\end{array}$ & $\begin{array}{l}0 \\
1.00 \\
0 \\
1\end{array}$ & $\begin{array}{l}0 \\
1.00 \\
0 \\
15\end{array}$ & $\begin{array}{l}0 \\
1.00 \\
0 \\
29\end{array}$ & $\begin{array}{l}0 \\
1.00 \\
0 \\
2\end{array}$ & $\begin{array}{l}0 \\
1.00 \\
0 \\
\quad 8\end{array}$ \\
\hline$M p i$ & $\begin{array}{l}1 \\
2 \\
3 \\
4 \\
5 \\
6 \\
n\end{array}$ & $\begin{array}{l}0 \\
1.00 \\
0 \\
0 \\
0 \\
0 \\
1\end{array}$ & $\begin{array}{l}0 \\
1.00 \\
0 \\
0 \\
0 \\
0 \\
15\end{array}$ & $\begin{array}{l}0 \\
1.00 \\
0 \\
0 \\
0 \\
0 \\
1\end{array}$ & $\begin{array}{l}0 \\
0.67 \\
0.33 \\
0 \\
0 \\
0 \\
3\end{array}$ & $\begin{array}{l}0 \\
0.50 \\
0 \\
0 \\
0.50 \\
0 \\
\quad 3\end{array}$ & $\begin{array}{l}0 \\
0.47 \\
0.05 \\
0.06 \\
0.41 \\
0.02 \\
33\end{array}$ & $\begin{array}{l}0 \\
0.42 \\
0.08 \\
0.17 \\
0.25 \\
0.08 \\
6\end{array}$ & $\begin{array}{l}0.25 \\
0.25 \\
0 \\
0 \\
0.50 \\
0 \\
\quad 8\end{array}$ & $\begin{array}{l}0 \\
0 \\
0.75 \\
0.25 \\
4\end{array}$ & $\begin{array}{l}0 \\
0 \\
0 \\
0 \\
1.00 \\
0 \\
1\end{array}$ & $\begin{array}{l}0 \\
0 \\
0 \\
0 \\
0.80 \\
0.20 \\
15\end{array}$ & $\begin{array}{c}0.88 \\
0.05 \\
29\end{array}$ & $\begin{array}{l}0 \\
0 \\
0 \\
0 \\
1.00 \\
0 \\
2\end{array}$ & $\begin{array}{l}0 \\
0 \\
0 \\
0 \\
0.81 \\
0.19 \\
8\end{array}$ \\
\hline Pepl & $\begin{array}{l}1 \\
2 \\
3 \\
n\end{array}$ & $\begin{array}{l}0 \\
1.00 \\
0 \\
1\end{array}$ & $\begin{array}{l}0 \\
1.00 \\
0 \\
16\end{array}$ & $\begin{array}{l}0 \\
1.00 \\
0 \\
1\end{array}$ & $\begin{array}{l}0 \\
1.00 \\
0 \\
3\end{array}$ & $\begin{array}{l}0 \\
1.00 \\
0 \\
3\end{array}$ & $\begin{array}{l}0.04 \\
0.96 \\
0 \\
34\end{array}$ & $\begin{array}{l}0 \\
1.00 \\
0 \\
6\end{array}$ & $\begin{array}{l}0.44 \\
0.56 \\
0 \\
8\end{array}$ & $\begin{array}{l}0 \\
1.00 \\
0 \\
4\end{array}$ & $\begin{array}{l}1.00 \\
0 \\
0 \\
1\end{array}$ & $\begin{array}{l}0.07 \\
0.93 \\
0 \\
15\end{array}$ & $\begin{array}{l}0.40 \\
0.60 \\
0 \\
29\end{array}$ & $\begin{array}{l}0 \\
1.00 \\
0 \\
2\end{array}$ & $\begin{array}{c}0.36 \\
0.50 \\
0.14 \\
7\end{array}$ \\
\hline Pep2 & $\begin{array}{l}1 \\
2 \\
3 \\
4 \\
5 \\
n\end{array}$ & $\begin{array}{l}0 \\
0 \\
1.00 \\
0 \\
0 \\
1\end{array}$ & $\begin{array}{l}0 \\
0.69 \\
0.31 \\
0 \\
0 \\
16\end{array}$ & $\begin{array}{l}0 \\
0.50 \\
0.50 \\
0 \\
0 \\
1\end{array}$ & $\begin{array}{l}0 \\
0.17 \\
0.83 \\
0 \\
0 \\
3\end{array}$ & $\begin{array}{l}0 \\
0 \\
1.00 \\
0 \\
0 \\
3\end{array}$ & $\begin{array}{l}0.09 \\
0.16 \\
0.74 \\
0.02 \\
0 \\
34\end{array}$ & $\begin{array}{l}0 \\
0.17 \\
0.83 \\
0 \\
0 \\
6\end{array}$ & $\begin{array}{l}0 \\
0.25 \\
0.56 \\
0.19 \\
0 \\
\quad 8\end{array}$ & $\begin{array}{l}0 \\
0 \\
1.00 \\
0 \\
0 \\
4\end{array}$ & $\begin{array}{l}0 \\
0 \\
1.00 \\
0 \\
0 \\
1\end{array}$ & $\begin{array}{l}0 \\
0 \\
0.97 \\
0.03 \\
0 \\
15\end{array}$ & $\begin{array}{l}0 \\
0 \\
0.93 \\
0.05 \\
0.02 \\
29\end{array}$ & $\begin{array}{l}0 \\
0 \\
1.00 \\
0 \\
0 \\
2\end{array}$ & $\begin{array}{l}0 \\
0 \\
1.00 \\
0 \\
0 \\
\quad 8\end{array}$ \\
\hline Рер3 & $\begin{array}{l}1 \\
2 \\
3 \\
n\end{array}$ & $\begin{array}{l}1.00 \\
0 \\
0 \\
1\end{array}$ & $\begin{array}{l}0.97 \\
0.03 \\
0 \\
16\end{array}$ & $\begin{array}{l}0.50 \\
0.50 \\
0 \\
1\end{array}$ & $\begin{array}{l}1.00 \\
0 \\
0 \\
3\end{array}$ & $\begin{array}{c}0.50 \\
0.33 \\
0.17 \\
3\end{array}$ & $\begin{array}{c}0.49 \\
0.22 \\
0.30 \\
34\end{array}$ & $\begin{array}{c}0.50 \\
0.33 \\
0.17 \\
6\end{array}$ & $\begin{array}{c}0.56 \\
0.13 \\
0.31 \\
8\end{array}$ & $\begin{array}{l}0 \\
0.50 \\
0.50 \\
4\end{array}$ & $\begin{array}{l}0 \\
1.00 \\
0 \\
1\end{array}$ & $\begin{array}{c}0.03 \\
0.90 \\
0.07 \\
15\end{array}$ & $\begin{array}{l}0 \\
0.50 \\
0.50 \\
29\end{array}$ & $\begin{array}{l}0 \\
0.50 \\
0.50 \\
2\end{array}$ & $\begin{array}{l}0 \\
0.31 \\
0.69 \\
8\end{array}$ \\
\hline Pgm & $\begin{array}{l}1 \\
2 \\
3 \\
4 \\
5 \\
n\end{array}$ & $\begin{array}{l}0.50 \\
0.50 \\
0 \\
0 \\
0 \\
1\end{array}$ & $\begin{array}{l}0.17 \\
0.47 \\
0.37 \\
0 \\
0 \\
15\end{array}$ & $\begin{array}{l}0 \\
0.50 \\
0.50 \\
0 \\
0 \\
1\end{array}$ & $\begin{array}{l}0.17 \\
0.33 \\
0.50 \\
0 \\
0 \\
3\end{array}$ & $\begin{array}{l}0.17 \\
0.33 \\
0 \\
0.17 \\
0.33 \\
\quad 3\end{array}$ & $\begin{array}{l}0.28 \\
0.15 \\
0 \\
0.54 \\
0.03 \\
34\end{array}$ & $\begin{array}{l}0.33 \\
0.17 \\
0 \\
0.42 \\
0.08 \\
6\end{array}$ & $\begin{array}{l}0 \\
0.38 \\
0.13 \\
0.38 \\
0.13 \\
8\end{array}$ & $\begin{array}{l}0 \\
0.25 \\
0 \\
0.63 \\
0.13 \\
\quad 4\end{array}$ & 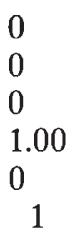 & $\begin{array}{c}0.13 \\
0.03 \\
0.07 \\
0.40 \\
0.37 \\
15\end{array}$ & $\begin{array}{l}0.02 \\
0.02 \\
0.13 \\
0.84 \\
0 \\
28\end{array}$ & $\begin{array}{l}0 \\
0 \\
0 \\
1.00 \\
0 \\
2\end{array}$ & $\begin{array}{l}0 \\
0 \\
0.50 \\
0.25 \\
0.25 \\
8\end{array}$ \\
\hline
\end{tabular}

Clones were established and tested at nine polymorphic loci. cuc, D. cucullata; $c \times h, D$. cucullata $\times$ hyalina; hya, $D$. hyalina. Abbreviations cf. Table 1 and text. 
Distances were calculated for pairs of populations from different hierarchical levels: within species, between species and between species and hybrids. The estimate $\mathrm{Nm}$ of gene flow was $F_{\mathrm{ST}}$-based using the formula $F_{\mathrm{ST}}=1 /(1+4 N m)$ by assuming an infinite island model at equilibrium. The relationship between $\mathrm{Nm}$ and geographical distance for all pairs of populations was analysed by a regression of $\log$ $\mathrm{Nm}$ on log distance (Slatkin, 1993). The significance of the correlation was tested using a Mantel randomization test and 1000 permutations (Mantel, 1967).

\section{Results}

\section{Spatial distribution and genetic variability}

The geographical origin of populations is presented in Fig. 1 and in Tables 1 and 2. In three lakes, only $D$. hyalina was found; in one lake, only D. cucullata. In four lakes $D$. cucullata-hyalina hybrids co-occurred with both parents. In one lake (Seeleitensee), $c \times h$ hybrids co-occurred with a hyalina-like morph (exact taxonomic status uncertain). The sample from the distant Meerfelder Maar $500 \mathrm{~km}$ away included only $c \times h$ hybrids without parental forms. Possibly, with more sampling, the missing taxa would have been found.

The allele frequencies at three polymorphic loci in the contemporaneous May/June 1985 samples are given in Table 1. Two alleles were found at the Gpi and Got loci, and five alleles at the Pgm locus for $D$. hyalina. There was evidence of restricted exchange between the two lake districts: allele 1 at the $G p i$ locus and allele 2 at the Pgm locus were only found in lakes in district I, whereas allele 3 at the Pgm locus was restricted to district II (Table 1). Considering sample size, most genotypes that might have been expected on the basis of allele frequencies were actually found. Altogether, 45 three-locus genotypes were collected, which corresponds to 33 per cent of 135 possible combinations. Diversity was largest in the Brunnsee with 31 genotypes. For samples of $>50$ animals, the average number of genotypes per lake was $17.8 \pm 7.9$ (SD). Numerous collections in 1983-85 in districts I and II extended the array considerably: 74 genotypes were identified (54.8 per cent of 135 possible combinations) in altogether 8506 individuals (data not shown here). The allelic array of $D$. cucullata (June 1985) differed from that of $D$. hyalina (Table 1). The Got locus was fixed for allele 1, which was never found in $D$. hyalina. There were three alleles at the Gpi locus, and all six possible genotypes were found. At the
Pgm locus, the three slowest alleles $(1,2,3)$ and all their possible genotypes were found. In contrast to $D$. hyalina, there were no differences in the allelic arrays of different districts. Altogether 23 (38 per cent) of 60 possible genotypes were found. The highest number was observed in Hartsee and Griessee (13 genotypes); average diversity was $13.0 \pm 0$ (SD) for samples of $>40$ animals. For the $c \times h$ hybrid group, the allelic and genotypic arrays were also the same in both districts (Table 1). All but a few genotypes corresponded to the allele combination of the parents. Exceptions were genotype 22 at the Gpi locus and genotype 44 at the Pgm locus. Presumably, backcrossing was involved. Some genotypes, which might have been expected on the basis of allele frequencies in the parental taxa, were not found in hybrids: these were genotype 13 at the Gpi locus and, at the Pgm locus, most genotypes involving alleles 1 or $3\left(\chi^{2}\right.$-tests, $\left.P<0.05\right)$. This suggests that some allele combinations may lead to inviable hybrids, or are strongly selected against. Altogether, 34 (24 per cent) of 140 possible combinations were found. The highest diversity was in Hartsee (24 genotypes); average diversity was $13.0 \pm 9.7$ (SD) for samples of $>40$ animals.

Generally, the nine-locus analysis of clones collected between 1985 and 1987 confirmed the three-locus data (Table 2). But there were also some differences. Pgm alleles 2 and 3 of D. hyalina were now found in both districts. For some loci, the genotypic composition of the $c \times h$ group was quite different in different districts. In district II, the genotype 12 at the $M d h$ locus was much more frequent than expected on the basis of allele frequencies $\left(\chi^{2}\right.$-test, $\left.P<0.001\right)$, further suggesting that some hybrid genotypes may be under-represented because of selection, whereas others might be favoured by selection. In the remote district III (Meerfelder Maar), all hybrids exhibited genotype 13 at the Gpi locus, which was missing in southern Germany. Private alleles were found at the $\mathrm{Mpi}$ locus (allele 1, Table 2).

Deviations from Hardy-Weinberg $(\mathrm{H}-\mathrm{W})$ expectations in May/June 1985 field samples are shown in Table 1 . For $D$. hyalina, the deviations were significant in 33 per cent of all cases, based on eight populations and three loci. For $D$. cucullata, deviations were significant in 80 per cent of all cases, based on five populations and two polymorphic loci. It should be noted that there was no consistent pattern in the direction of deviations in either of the two species. For the $c \times h$ hybrids, the deviation was significant in 95 per cent of all cases, based on three 
loci and four populations. Except for Pgm in the Seeleitensee, there was an excess of heterozygotes.

\section{Genetic differentiation}

Both data sets were analysed: the May/June samples of 1985 based on five or four populations per taxon (one site per lake) and three loci, and the clones collected between 1985 and 1987 based on six or four populations per taxon and nine loci (cf. Table $3)$. In all taxa, $F_{S T}$ values were highly divergent among loci in the nine-locus data set. For $D$. hyalina (May 1985), $F_{\mathrm{ST}}$ values ranged from 0.104 (Gpi) to $0.250(G o t)$; the overall $F_{\mathrm{ST}}$ equalled 0.212 and was different from $0(P<0.05)$. Similar mean $F_{\mathrm{ST}}$ values were obtained in the analysis of clones for the same three loci and for all nine loci. For $D$. cucullata, the $F_{\text {ST }}$ values were in a similar range $(0.118-0.281$,

Table 3 Weir \& Cockerham's (1984) $F_{\text {ST }}$ estimator (Goudet, 1995) for population samples screened at three loci (May/June 1985 samples) and nine loci (samples between 1985 and 1987)

\begin{tabular}{|c|c|c|c|c|c|c|c|c|}
\hline \multirow[b]{2}{*}{ Taxon } & \multicolumn{4}{|c|}{ Three loci } & \multicolumn{4}{|c|}{ Nine loci } \\
\hline & & $F_{\mathrm{ST}}$ & $\mathrm{SD}$ & $n$ & & $F_{\mathrm{ST}}$ & $\mathrm{SD}$ & $n$ \\
\hline \multicolumn{9}{|c|}{ D. hyalina } \\
\hline & $G p i$ & $\underline{0.104}$ & 0.031 & 5 & $G p i$ & $\underline{0.195}$ & 0.106 & 6 \\
\hline & Got & $\overline{0.250}$ & 0.079 & 5 & Got & $\overline{0.204}$ & 0.119 & 6 \\
\hline & Pgm & 0.192 & 0.024 & 5 & $P g m$ & 0.273 & 0.130 & 6 \\
\hline & & & & & Ao & $\overline{0.702}$ & 0.303 & 6 \\
\hline & & & & & $M d h$ & $\underline{0.469}$ & 0.249 & 6 \\
\hline & & & & & $M p i$ & 0.027 & 0.058 & 6 \\
\hline & & & & & Pep1 & $\underline{0.130}$ & 0.165 & 6 \\
\hline & & & & & Рep2 & -0.021 & 0.042 & 6 \\
\hline & & & & & Рep3 & 0.193 & 0.235 & 6 \\
\hline & All loci & $\underline{0.212}$ & 0.029 & 5 & All loci & $\underline{0.204}$ & 0.031 & 6 \\
\hline \multicolumn{9}{|c|}{ D. cucullata } \\
\hline & $G p i$ & $\underline{0.118}$ & 0.061 & 5 & $G p i$ & $\underline{0.149}$ & 0.154 & 4 \\
\hline & Got & undef & undef & 5 & Got & $\overline{\text { undef }}$ & undef & 4 \\
\hline & Pgm & $\underline{0.281}$ & 0.213 & 5 & $P g m$ & 0.085 & 0.165 & 4 \\
\hline & & & & & Ao & undef & undef & 4 \\
\hline & & & & & $M d h$ & undef & undef & 4 \\
\hline & & & & & $M p i$ & undef & undef & 4 \\
\hline & & & & & Pep1 & undef & undef & 4 \\
\hline & & & & & Рep2 & 0.262 & 0.217 & 4 \\
\hline & & & & & Pep3 & 0.353 & 0.504 & 4 \\
\hline & All loci & $\underline{0.224}$ & 0.067 & 5 & All loci & 0.165 & 0.242 & 4 \\
\hline \multicolumn{9}{|c|}{$c \times h$ hybrids } \\
\hline & $G p i$ & $\underline{0.010}$ & 0.019 & 4 & $G p i$ & $\underline{0.201}$ & 0.097 & 4 \\
\hline & Got & $\overline{0.146}$ & 0.068 & 4 & Got & $\overline{0.004}$ & 0.100 & 4 \\
\hline & $P g m$ & $\underline{0.181}$ & 0.118 & 4 & $P g m$ & $\underline{0.128}$ & 0.076 & 4 \\
\hline & & & & & Ao & $\overline{0.006}$ & 0.007 & 4 \\
\hline & & & & & $M d h$ & 0.063 & 0.058 & 4 \\
\hline & & & & & $M p i$ & 0.039 & 0.040 & 4 \\
\hline & & & & & Pep1 & 0.579 & 0.345 & 4 \\
\hline & & & & & Pep2 & 0.016 & 0.045 & 4 \\
\hline & & & & & Pep3 & 0.116 & 0.120 & 4 \\
\hline & All loci & $\underline{0.134}$ & 0.048 & 4 & All loci & $\underline{0.085}$ & 0.020 & 4 \\
\hline
\end{tabular}

For Daphnia hyalina, only site 1 is included for the lakes with two sampling sites. $n$, number of populations; SD, standard deviation estimated by jackknifing over populations and loci, respectively. $F_{\mathrm{ST}}$ values significantly different from 0 with $P<0.05$ (permutation tests) are underlined; undef, undefined. 
three-locus data set; $0.085-0.353$, nine-locus data set; Table 3$)$ and the overall $F_{\mathrm{ST}}$ values $(0.224$ and $0.165)$ were different from $0(P<0.05)$, at least for the three-locus data. As in $D$. hyalina, the overall $F_{\mathrm{ST}}$ value indicates a medium level of genetic differentiation between subpopulations. About 80 per cent of the total genetic variation was found within populations of both species. Surprisingly, the values for the $c \times h$ populations were low: $F_{\mathrm{ST}}$ values ranged from 0.010 to 0.181 for single loci, and equalled about 0.1 over three as well as nine loci. The overall $F_{\mathrm{ST}}$ values were different from $0(P<0.05)$. This implies significant, but quite small, genetic divergence between hybrid subpopulations. The level of genetic differentiation between populations of the same taxon from different lakes was significantly lower than between taxa. Post hoc comparisons of mean $F_{\mathrm{ST}}$ (three loci, Bonferroni tests) showed a three-level hierarchical structure: mean $F_{\mathrm{ST}}$ values between populations from the same taxon (cuc-cuc: $0.174 \pm 0.163 \mathrm{SD}$, $n=10$; hya-hya: $0.176 \pm 0.127, n=10 ; c \times h-c \times h$ : $0.121 \pm 0.083, n=6)$ were significantly $(P<0.05)$ lower than between populations from parent species and hybrids $($ cuc $-c \times h: 0.298 \pm 0.077, \quad n=20$; hya $-c \times h: 0.340 \pm 0.084, n=20$ ), which again were lower than mean $F_{\mathrm{ST}}$ values between populations from different species (cuc-hya: 0.619 \pm 0.055 , $n=25$ ). When $F_{\mathrm{ST}}$ values are converted to rates of gene flow $(\mathrm{Nm})$, gene flow rates between populations from different lakes of the same taxon were considerably higher than the rates between taxa, suggesting sufficient reproductive isolation. On average, for both species one propagule per generation can be assumed to be exchanged between populations, and two propagules per generation between populations of the hybrids.

\section{Genetic distance}

Figure 2 shows the within-taxa and between-taxa variance of $D_{\text {nei }}$ based on three and nine loci. As expected, values based on nine loci are mostly lower. Intraspecific distance values $D_{\text {nei }}$ were considerably lower (mean $0.14 \pm 0.09$ SD for three loci, and $0.11 \pm 0.09$ for nine loci) than interspecific values $(2.05 \pm 0.63$ and $1.16 \pm 0.32)$. On the other hand, distances between parents and hybrids $(0.3 \pm 0.13$ and $0.25 \pm 0.13$ ) were more similar to intraspecific ranges. In both data sets, post hoc comparisons of mean $D_{\text {nei }}$ (Bonferroni tests) again showed a threelevel hierarchical structure $(P<0.05)$ : mean $D_{\text {nei }}$ values between populations from the same taxon were significantly lower than between populations from parent species and hybrids, which again were

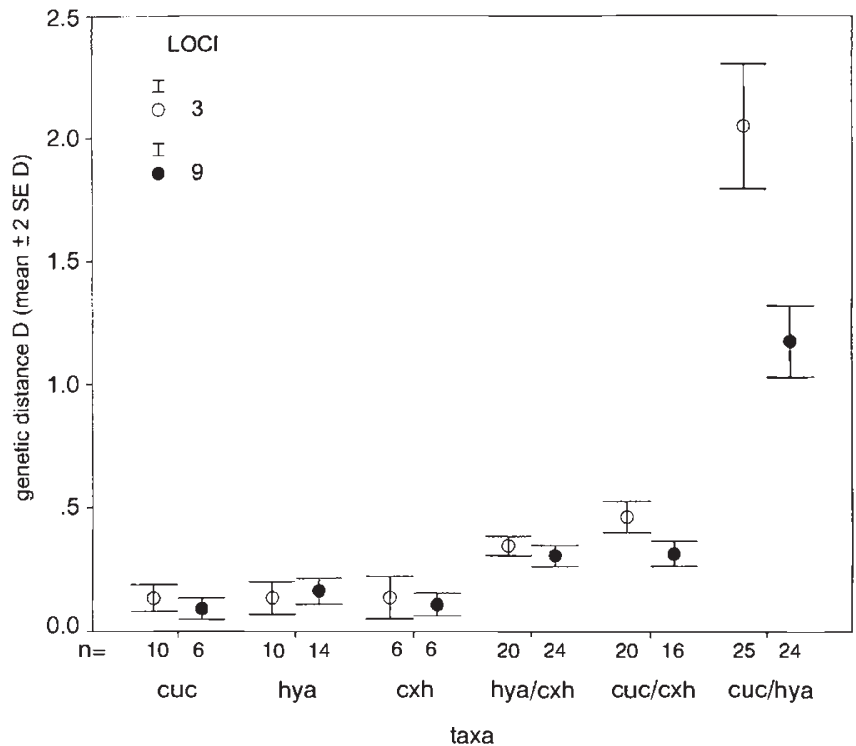

Fig. 2 Hierarchical analysis of genetic distances $\left(D_{\text {nei }}\right)$ based on three and nine loci. Pairwise genetic distances based on (i) populations from the same taxon; (ii) populations from parent species and hybrids; and (iii) populations from different species. $n$, number of populations.

lower than mean $D_{\text {nei }}$ values between populations from different species.

\section{Gene flow}

Figure 3 shows the relationship between the log of gene flow $(\mathrm{Nm})$ and the log of the distance between

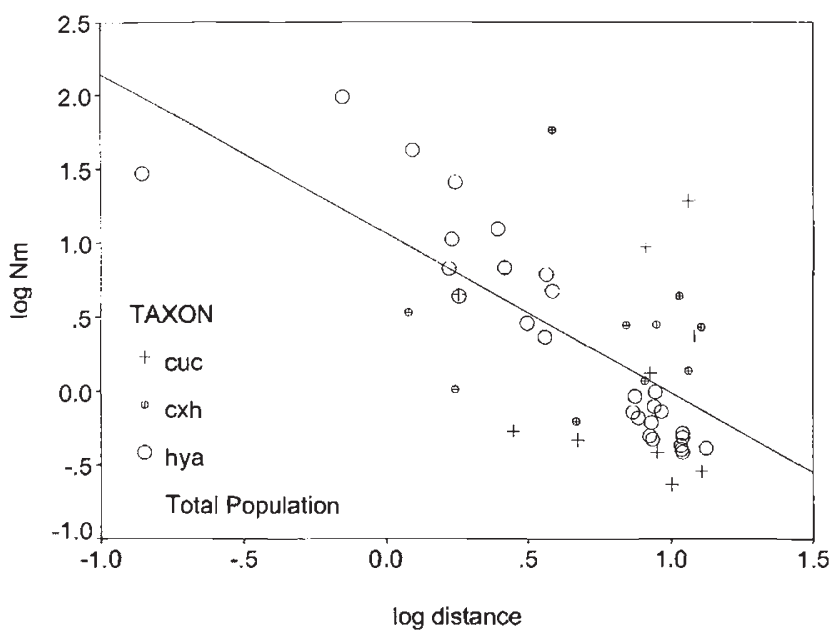

Fig. 3 Linear regression of $\log$ gene flow $(\mathrm{Nm})$ against $\log$ of distance between all pairs of populations within species and hybrids based on the three-locus data set. The line refers to the overall regression $\log \mathrm{Nm}=1.066-0.656 \log$ distance, with an $r^{2}$ value of 0.43 .

(C) The Genetical Society of Great Britain, Heredity, 79, 231-241. 
pairs of populations based on three loci. An overall negative regression $(\log N m=1.066-0.656 \quad \log$ distance, $r^{2}=0.43$ ) indicates isolation by distance, but there are differences between taxa. A highly significant negative regression was found for populations of $D$. hyalina in both data sets $\left(P_{(\text {Mantel })}<0.01\right)$, with $\log$ distance explaining 82 per cent of the variation in $\log \mathrm{Nm}$ values in the three-locus data set $(y=1.239-1.425 x$, Fig. 3). For populations of $D$. cucullata and the hybrid populations, the regression was also negative in both data sets. For D. cucullata, the regression was nearly significant in the threelocus data set $\left(y=0.190-0.082 x, P_{\text {(Mantel) }}=0.06\right)$, whereas for hybrid populations the regression was only significant in the nine-locus data set $\left(y=0.526-0.094 x, P_{\text {(Mantel) }}=0.012\right)$, in which animals from the distant Meerfelder Maar population were included. I conclude that, for all three taxa, gene flow between lakes would satisfactorily explain the correlations described. However, in all taxa, some populations were genetically more divergent than close geographical neighbourhood would imply. This was most pronounced in the $c \times h$ population from the Seeleitensee and the $D$. cucullata population from the Griessee, suggesting that selection is greater than rates of gene flow locally.

\section{Discussion}

\section{Genetic structure of populations}

The genetic variability in populations of the $D$. cucullata-hyalina complex corresponds to a recent study on the D. galeata-cucullata complex (Spaak, 1996). Clonal diversity based on three-locus genotypes was high for all taxa and intermediate for hybrids. Over the whole sampling period, 74 different clonal groups were found for D. hyalina, followed by 34 for $c \times h$ hybrids and 23 for $D$. cucullata. It is unclear why this high level of variation persists in natural populations. A great part of this variability should be eliminated because populations become increasingly adapted to local conditions. One hypothesis is that differential selection in a heterogeneous environment maintains selectively important genetic variation (Levene, 1953). In large lakes, fluctuating selection on ecologically different genotypes (Weider \& Stich, 1992; Spaak \& Hoekstra, 1995) would explain the maintenance of high genetic diversity. $F_{\mathrm{ST}}$ values were in the same range as has been described for lake populations of $D$. galeata and D. longispina (0.01-0.27; Mort, 1991) and suggest substantial genetic substructuring among populations. $F_{\mathrm{ST}}$ values beyond 0.2 are unlikely to result from random genetic drift in large populations but are more probably caused by local selection.

Deviations from Hardy-Weinberg proportions suggest a low frequency of sexual reproduction for populations of $D$. cucullata and especially for the $c \times h$ hybrids, whereas bisexual reproduction may be more frequent in $D$. hyalina. This is in contrast to the study on the $D$. galeata-cucullata complex in which all three taxa were in $\mathrm{H}-\mathrm{W}$ equilibrium (Spaak, 1996). In D. hyalina and D. cucullata, the direction of deviations indicated heterozygote excess as well as deficiencies. This is consistent with the finding that the development of deviations was linked to a low frequency of bisexuality and long parthenogenetic phases (cf. Hebert \& Moran, 1980; Wolf \& Mort, 1986; Hebert, 1987; Jacobs, 1990). For $c \times h$ hybrids, however, heterozygotic excess was the rule (91 per cent). This is fully consistent with typical hybrid genomes. The hierarchical analyses of genetic diversity $\left(F_{\mathrm{ST}}\right)$ and genetic distance $\left(D_{\text {nei }}\right)$ both give evidence of restricted gene flow between species and hybrids. As expected, hybrids were genetically intermediate, strongly supporting correct taxonomic identification of animals.

\section{Gene flow}

MtDNA and RAPD data have suggested recurrent hybridization in large-lake species (Schwenk, 1993; Schierwater et al., 1994). This is consistent with multiple multilocus genotypes observed in $c \times h$ hybrid populations here, which implies multiple hybridization events. One would expect highly divergent hybrid populations based on the locally different genetic structures of parent populations. Surprisingly, the genetic divergence between 'conspecific' populations was lowest in $c \times h$ hybrids. Mean $F_{\mathrm{ST}}$ values about 0.1 would suggest rather panmictic $c \times h$ hybrid populations and high gene flow between lakes. Assuming similar dispersal for hybrids and parental species, gene flow rates twice as large in hybrids seem to be very unlikely. One possible explanation is that prezygotic selection or restricted fitness of certain hybrid genotypes result in similar genotypic compositions of hybrid populations in different habitats.

Based on private alleles (Slatkin, 1985), the effective number of migrants per generation $(\mathrm{Nm})$ was much higher than that derived from $F_{\mathrm{ST}}$ (data not shown here), which is presumably caused by small sample sizes. $F_{\mathrm{ST}}$-based estimates of $\mathrm{Nm}$ were used to test for isolation by distance (Slatkin, 1993). The relationship was most pronounced for populations of $D$. hyalina but was also evident when all samples, 
taxa and sampling times were pooled. One may conclude that levels of gene flow are high but geographically restricted. Long-distance dispersal seems to be rare, and colonization of habitats is not recent, otherwise patterns of isolation by distance would not have been detected in the large populations sampled here. However, some populations were genetically far more distant from neighbouring populations than expected. Differences in the ecology of the habitats may reflect different selection on the genotypic composition. In $D$. cucullata, the deviating population originated from the Griessee, the unique lake with dystrophic character and presumably different ecology. On the other hand, the genetic composition of the deviating $c \times h$ population in the Seeleitensee, might have been influenced by introgression from coexisting hyalinalike morphs. Thus, the results of my study may be interpreted as the outcome of local selection and differential introgression, which is superimposed by dispersal.

Similar mechanisms of dispersal may be assumed for pond Daphnia and large-lake Daphnia. However, despite numerous analyses of pond populations, even indirect evidence for patterns of isolation by distance is the exception (cf. Wolf \& Hobaek, 1986; Weider \& Hebert, 1987; Boileau \& Taylor, 1994). This could be considered the result of infrequent local extinctions and recolonizations of ponds by a few individuals. Indeed, in contrast to large-lake Daphnia, in which clonal groups seem to be widely distributed, pond species belong to the most extremely subdivided species (Crease et al., 1990), with ponds dominated by a few unique clones (Hebert \& Crease, 1983), most pronounced in small temporary habitats. If pond species have colonized the current habitat very recently, there would be less time for isolation by distance to become apparent. Different mosaics of ecologically similar habitats, the age of the habitat, founder effects, random genetic drift during colonization and local selection greater than the gene flow rate may altogether account for the pronounced differences observed in pond Daphnia.

In hybridizing large-lake Daphnia complexes a realistic scenario could be as follows. Local parental groups principally determine the local genotypic composition of hybrids. Assuming that similarities between hybrid populations of different lakes are brought about by strong selection on hybrids and recurrent local hybridization is resulting in similar hybrid genotypes in different lakes, only a few hybrid genotypes would reflect local genetic differences in parental taxa. The local genotypic composi- tion of hybrids and the effect of long-distance migration might both be strongly disturbed by selection. Individuals will only colonize new habitats successfully if they can coexist with long-term established communities. The geographical mosaic of ecologically similar habitats will determine the success of colonizers. Within lakes, a high number of gradually different niches would allow ecologically different genotypes to coexist. I conclude that the ecological similarity of neighbouring habitats strongly influences the significance of exchange relative to lake-specific selection.

\section{Acknowledgements}

The research was supported by DFG Ja 145/14-2. The manuscript writing was enabled by a HSPII grant from the LMU University of Munich. I am grateful to Jürgen Jacobs and Hans Siegismund for critical comments on earlier versions of the manuscript, to two reviewers who further improved the manuscript, to Steve McLaughlin for polishing the English, and to Jakob Müller for collecting the Meerfelder Maar samples. Hans Siegismund also provided advice on data analysis. I am specially indebted to my young daughter Kim for enduring my absence at weekends too.

\section{References}

BOILEAU, M. C. AND TAYLOR, B. E. 1994. Chance events, habitat age, and the genetic structure of pond populations. Arch. Hydrobiol., 132, 191-202.

CREASE, T. J., LYNCH, M. AND SPITZE, K. 1990. Hierarchical analysis of population genetic variation in mitochondrial and nuclear genes of Daphnia pulex. Mol. Biol. Evol., 7, 444-458.

GIEßLER, s. 1987. Mikroevolution und Populationsgenetik im Daphnia galeata/hyalina/cucullata-Komplex (Crustacea: Cladocera). Eine Freilandanalyse. Doctoral thesis, Fakultät Biologie, University of Munich, Germany.

G1EßLER, s. 1997. Analysis of reticulate relationships within the Daphnia longispina complex. Allozyme phenotype and morphology. J. Evol. Biol., 10, 87-105.

GOUDET, J. 1995. FSTAT. Distributed by the author. Institute de Zoologie et d'Ecologie Animale, Université de Lausanne, Dorigny, Switzerland.

GuO, S. W. AND THOMPSON, E. A. 1992. Performing the exact test for Hardy-Weinberg proportions for multiple alleles. Biometrics, 48, 361-372.

HEBERT, P. D. N. 1985. Interspecific hybridization between cyclic parthenogens. Evolution, 39, 216-220.

HEBERT, P. D. N. 1987. Genotypic characteristics of the Cladocera. Hydrobiologia, 145, 183-193.

HEBERT, P. D. N. AND BEATON, M. J. 1989. Methodologies for Allozyme Analysis using Cellulose Acetate Electrophoresis: 
a Practical Handbook. Helena Laboratories, Beaumont, Texas.

HEBERT, P. D. N. AND CREASE, T. 1983. Clonal diversity in populations of Daphnia pulex reproducing by obligate parthenogenesis. Heredity, 51, 353-369.

HEBERT, P. D. N. AND MORAN, C. 1980. Enzyme variability in natural populations of Daphnia carinata. Heredity, 45, 313-321.

HEBERT, P. D. N., SCHWARTZ, S. S. AND HRBACEK, J. 1989. Patterns of genotypic diversity in Czechoslovakian Daphnia. Heredity, 62, 207-216.

JACOBS, J. 1990. Microevolution in predominantly clonal populations of pelagic Daphnia (Crustacea: Phyllopoda): selection, exchange, and sex. J. Evol. Biol., 3, 257-282.

LEVENE, H. 1953. Genetic equilibrium when more than one ecological niche is available. Am. Nat., 87, 331-333.

MANTEL, N. 1967. The detection of disease clustering and a generalized regression approach. Cancer Res., 27, 209-220.

MORT, M. A. 1991. Bridging the gap between ecology and genetics: the case of freshwater zooplankton. Trends Ecol. Evol., 6, 41-45.

MORT, M. A. AND WOLF, H. G. 1986. The genetic structure of large-lake Daphnia populations. Evolution, 40, 756-766.

Müller, J. 1993. Räumliche und zeitliche Variabilität der genetischen Struktur natürlicher Cladocerenpopulationen (Crustacea, Cladocera). Doctoral thesis, J. Gutenberg Universität, Mainz, Germany.

NEI, M. 1972. Genetic distance between populations. Am. Nat., 106, 283-291.

RAYMOND, M. AND ROUSSET, F. 1995. GENEPOP (Version 1.2): A population genetics software for exact tests and ecumenicism. J. Hered., 86, 248-249.

SCHIERWATER, B., ENDER, A., SCHWENK, K., SPAAK, P. AND STREIT, B. 1994. The evolutionary ecology of Daphnia. In: Schierwater, B., Streit, B., Wagner, G. and DeSalle, R. (eds) Molecular Approaches to Ecology and Evolution, pp. 495-508. Birkhäuser Verlag, Basel.

sCHWENK, K. 1993. Interspecific hybridization in Daphnia: distinction and origin of hybrid matrilines. Mol. Biol. Evol., 10, 1289-1302.

SIEBECK, O. 1991. Die Seen in den Naturschutzgebieten 'Eggstätt-Hemhofer Seenplatte' und 'Seeoner Seen'
-Zustand, Gefährdung und Problematik ihres Schutzes. In: Rundgespräche der Kommission für Ökologie, 'Ökologie der oberbayrischen Seen', 2, 119-145. Verlag Dr Friedrich Pfeil, Munich.

SLATK1N, M. 1985. Rare alleles as indicators of gene flow. Evolution, 39, 53-65.

SLATKIN, M. 1987. Gene flow and the geographic structure of natural populations. Science, 236, 787-792.

SLATK1N, M. 1993. Isolation by distance in equilibrium and non-equilibrium populations. Evolution, 47, 264-279.

SPAAK, P. 1996. Temporal changes in the genetic structure of the Daphnia species complex in Tjeukemeer with evidence for backcrossing. Heredity, 76, 539-548.

SPAAK, P. AND HOEKSTRA, R. 1995. Life history variation and the coexistence of a Daphnia hybrid and its parental species. Ecology, 76, 553-564.

TAYLOR, D. J. AND HEBERT, P. D. N. 1992. Daphnia galeata mendotae as a cryptic species complex with interspecific hybrids. Limnol. Oceanogr., 37, 658-665.

TAYLOR, D. J. AND HEBERT, P. D. N. 1993. Habitatdependent hybrid parentage and differential introgression between neighboringly sympatric Daphnia species. Proc. Natl. Acad. Sci. U.S.A., 90, 7079-7083.

WEIDER, L. J. AND HEBERT, P. D. N. 1987. Microgeographic genetic heterogeneity of melanic Daphnia pulex at a low-Arctic site. Heredity, 58, 391-399.

WEIDER, L. J. AND STICH, H. B. 1992. Spatial and temporal heterogeneity of Daphnia in Lake Constance: intra- and interspecific comparisons. Limnol. Oceanogr., 37, 1327-1334.

WEIR, B. S. AND COCKERHAM, c. c. 1984. Estimating $F$-statistics for the analysis of population structure. Evolution, 38, 1358-1370.

WOLF, H. G. 1982. A comparison of different electrophoretic techniques for the detection of isoenzymes in single Daphnids. Arch. Hydrobiol., 95, 521-531.

WOLF, H. G. AND HOBAEK, A. 1986. Ecological genetics of Norwegian Daphnia. I. Genetic differentiation between pigmented und unpigmented alpine pond populations. Hereditas, 104, 193-198.

WOLF, H. G. AND MORT, M. A. 1986. Inter-specific hybridization underlies phenotypic variability in Daphnia populations. Oecologia, 68, 507-511. 